\title{
Factors Affecting the Development of Wood Rot on Lemon Trees Infected with Antrodia sinuosa, Coniophora eremophila, and a Nodulisporium sp.
}

\author{
M. E. Matheron and M. Porchas, Yuma Agricultural Center, The University of Arizona, Yuma 85364; and \\ D. M. Bigelow, Department of Plant Sciences, Division of Plant Pathology and Microbiology, The University of Ari- \\ zona, Tucson 85721
}

\begin{abstract}
Matheron, M. E., Porchas, M., and Bigelow, D. M. 2006. Factors affecting the development of wood rot on lemon trees infected with Antrodia sinuosa, Coniophora eremophila, and a Nodulisporium sp. Plant Dis. 90:554-558.

Brown heartwood rot, which often is found in branches within lemon groves in southwestern Arizona, is caused by two basidiomycete fungi, Antrodia sinuosa and Coniophora eremophila. Another fungus, a species of Nodulisporium, has been recovered from small, dying lemon tree branches with an internal white wood rot. Studies were conducted from 1999 through 2002 to compare the extent of wood decay caused by these fungi (i) on lemon tree branches at different times of the year, (ii) on different types of citrus, (iii) on some desert woody perennial plants, and (iv) on lemon tree branches treated with selected fungicides. The mean length of wood decay columns recorded in lemon tree branches inoculated with A. sinuosa, C. eremophila, and the Nodulisporium sp. during the time periods of November to January, February to April, May to July, and August to October was 2.9, 4.7, 13.3, and $15.2 \mathrm{~cm}$, respectively. There was a significant linear correlation between the length of wood decay columns and air temperature for all three pathogens. The mean length of wood decay columns for all time periods in branches inoculated with A. sinuosa, C. eremophila, and the Nodulisporium sp. was $11.8,5.8$, and $9.6 \mathrm{~cm}$, respectively. In two trials, wood decay columns were significantly greater on Lisbon lemon tree branches inoculated with $A$. sinuosa compared with those on Marsh grapefruit and Valencia orange trees inoculated with the same pathogen. Wood decay in the presence of the Nodulisporium $\mathrm{sp}$. was greater on branches of lemon compared with grapefruit trees in two trials and on lemon compared with orange trees in one of two trials. With the exception of $C$. eremophila on creosote bush, each of the three wood rot pathogens caused some wood decay in branches of velvet mesquite, salt cedar, Mexican palo verde, and creosote bush, four common desert perennials found in southwestern Arizona. Compared with nontreated but inoculated lemon trees, the length of wood decay columns in branches inoculated with A. sinuosa, C. eremophila, and the Nodulisporium sp. in the presence of propiconazole was reduced by 79,94 , and $92 \%$, respectively, and, in the presence of azoxystrobin, was suppressed by 71,80 , and $89 \%$, respectively. Current management guidelines focus on minimizing branch fractures and other nonpruning wounds in conjunction with early detection and removal of infected branches before the onset of the increased wood decay development period extending from May to October.
\end{abstract}

In 1992, a species of Coniophora was first reported to be associated with a brown heartwood rot in lemon (Citrus limon) trees in southwestern Arizona (15). The wood decay had been observed in lemon plantings in this region for at least 30 years; however, the cause was previously unknown. Subsequent research revealed the identity of this basidiomycete to be Coniophora eremophila, the only species of this fungus thus far known to occur in the Sonoran desert region of Arizona and Mexico. C. eremophila was described in 1975 (14) and has been found fruiting on a number of species of desert trees, shrubs,

Corresponding author: M. E. Matheron

E-mail: matheron@ag.arizona.edu

Accepted for publication 29 November 2005.

DOI: 10.1094/PD-90-0554

(C) 2006 The American Phytopathological Society and cacti, mainly as a saprophyte on dead fallen wood and associated with a brown rot (9-11). In 1997, during surveys of mature orchards to determine the incidence of lemon trees infected with $C$. eremophila, a second basidiomycete fungus was isolated from symptomatic decayed wood and subsequently identified as Antrodia sinuosa.

$C$. eremophila and $A$. sinuosa cause brown heartwood rot in living lemon trees in southwestern Arizona and southeastern California (2). Similarities between the two pathogens include the following: each fungus grows optimally at approximately $35^{\circ} \mathrm{C}$ (2), neither organism produces a fleshy fruiting body, they colonize lemon trees primarily through branch fractures and other nonpruning wounds, and both cause a brown heartwood rot in infected lemon trees $(2,3)$. A major difference between the two pathogens is that $A$. sinuosa can form resupinate spore-producing fruiting bodies on infected wood within lemon groves, whereas fruiting on lemon wood infected with $C$. eremophila has not been observed. A. sinuosa potentially is more destructive than $C$. eremophila because it fruits readily on infected lemon trees in the field and, in a preliminary trial, produced wood decay columns significantly longer than those produced by C. eremophila (4).

A third fungus was recovered in 1999 from small dead branches on lemon trees in Yuma (16). Unlike the brown wood decay from which Antrodia and Coniophora spp. were recovered, this fungus was isolated from decayed wood that was white in color. This third fungus subsequently was identified as a species of Nodulisporium, a hyphomycete genus that contains anamorphs of members of the ascomycete family Xylariaceae (16).

Other wood-rotting fungi are implicated in diseases of citrus $(1,5-8,12,13,17-22)$. Some examples of reported diseases in citrus caused by basidiomycete pathogens include a root rot in Florida caused by Clitocybe tabescens $(13,22)$, a wood rot caused by a Ganoderma sp. in Florida (6), a root rot in California and Australia caused by Armillaria mellea $(5,17)$, and a butt rot in grapefruit (Citrus paradisi) in Texas caused by Ganoderma lucidum $(19,20)$. G. lucidum has been found in some old lemon groves in southwestern Arizona, but is not considered an important pathogen in this region.

The objectives of this research were to compare the extent of wood decay caused by Antrodia sinuosa, Coniophora eremophila, and the Nodulisporium sp. on (i) lemon tree branches at different times of the year, (ii) different types of citrus, (iii) some desert woody perennial plants, and (iv) lemon tree branches treated with selected fungicides.

\section{MATERIALS AND METHODS}

Effect of time of year on disease development. Isolates of $A$. sinuosa, $C$. eremophila, and the Nodulisporium sp. originally were recovered from symptomatic lemon trees growing in commercial lemon groves in Yuma County, AZ in 1992, 1997, and 1999, respectively. One isolate of each fungus was maintained on acidified potato dextrose agar (PDA) and used in all experiments. To prepare inoculum, autoclaved pieces of wood dowel $(5 \mathrm{~mm}$ in diameter by $13 \mathrm{~mm}$ long) were placed on mycelia of an isolate of $A$. sinuosa, $C$. eremophila, and the Nodulisporium sp. 
growing in 100-by-15-mm plastic petri dishes containing PDA, then incubated for 1 month in the dark at $28^{\circ} \mathrm{C}$. A planting of Lisbon lemon trees at least 30 years old was used in these studies. Branches ranging from 6 to $10 \mathrm{~cm}$ in diameter were inoculated by placing one dowel segment containing one of the fungi into a hole ( 6 $\mathrm{mm}$ in diameter by $26 \mathrm{~mm}$ long) drilled into a series of branches on living trees. The dowel segment containing the pathogen was positioned and retained in the bottom of each inoculation hole by driving another dowel piece not containing a fungus into each wound. This longer dowel piece was cut off flush with the surface of the branch and the wound was sealed with melted paraffin. Disease was assessed approximately 3 months later my removing inoculated branches, splitting them in half, and measuring the length of resultant decay columns. Control trees received dowel pieces that did not contain a pathogen. At each inoculation date, 10 replicate branches in total (1 replicate branch per tree per pathogen) were inoculated with each pathogen or received noncolonized dowel pieces. Inoculation dates were 17 November 1999 and 8 February, 18 May, and 25 July 2000 for the first year; and 28 October 2000 and 31 January, 3 May, and 27 July 2001 for the second year. For the first year, disease development was assessed $84,76,90$, and 95 days after inoculation at each respective date; and, for the second year, 95, 92, 84, and 95 days after inoculation at each respective date. Air temperature was recorded hourly for the duration of this study at an Arizona Meteorological Network (AZMET) station located less than 1 $\mathrm{km}$ from the site of the experiment.

Wood decay on different types of citrus. Branches ranging from 6 to $10 \mathrm{~cm}$ in diameter on approximately 30-year-old Lisbon lemon, Marsh grapefruit, and Valencia sweet orange $(C$. sinensis) trees were used in these studies. Inoculum consisting of autoclaved pieces of wood dowel colonized by A. sinuosa or the Nodulisporium $\mathrm{sp}$. were prepared and inserted into wounds in living branches as described previously. At each inoculation date, six replicate branches in total on lemon, grapefruit, and orange trees (one replicate branch per tree per pathogen) were inoculated with each pathogen or received noncolonized dowel pieces to serve as controls. Inoculation dates for the first and second year were 27 July 2000 and 16 August 2001, respectively. Disease development was assessed approximately 6 and 8 months later, respectively (5 February 2001 and 19 April 2002), by removing inoculated branches, splitting them in half, and measuring the resultant decay columns.

Wood decay on desert woody perennial plants. Branches ranging from 3 to 8 $\mathrm{cm}$ in diameter on Mexican palo verde (Parkinsonia aculeata), salt cedar (Tamarix pentandra), creosote bush (Larrea tridentata), and velvet mesquite (Prosopis glandulosa) growing in the desert were used in these studies. Inoculum consisting of autoclaved pieces of wood dowel colonized by A. sinuosa, Coniophora eremophila, or the Nodulisporium sp. were prepared and inserted into wounds in living branches as described previously. At each inoculation date, 10 replicate branches in total (one replicate branch per plant per pathogen) of each type of desert plant were inoculated with each pathogen or received noncolonized dowel pieces to serve as controls. Inoculation dates for the first and second year were 28 July 2000 and 17 August 2001, respectively. Disease development was assessed approximately 7 and 6 months later, respectively (20 February 2001 and 20 March 2002), by removing inoculated branches, splitting them in half, and measuring the resultant decay columns.

Fungicide studies. The following materials were evaluated in these field trials: azoxystrobin (Abound; Syngenta Crop Protection, Inc., Greensboro, NC), kresoxim-methyl (Sovran; BASF Corp., Research Triangle Park, NC), pyraclostrobin (Headline; BASF Corp.), trifloxystrobin (Flint; Bayer CropScience, Research Triangle Park, NC), and propiconazole (Tilt, Syngenta Crop Protection, Inc.). Branches ranging from 6 to $10 \mathrm{~cm}$ in diameter on approximately 30-year-old Lisbon lemon trees were used in these studies. Inoculum consisting of autoclaved pieces of wood dowel colonized by A. sinuosa, C. eremophila, or the Nodulisporium sp. were prepared and inserted into wounds in living branches as follows. A vertical hole $(6 \mathrm{~mm}$ in diameter by $26 \mathrm{~mm}$ long) was drilled into each branch to be inoculated. Prior to inoculating branches, an aqueous mixture of each fungicide was prepared that contained $20 \mathrm{mg}$ of active ingredient (a.i.) per milliliter. The hole in each branch then was filled with this fungicide solution. A piece of wood dowel $5 \mathrm{~mm}$ in diameter by 13 $\mathrm{mm}$ long, previously colonized with one of the three pathogens, was coated with the same fungicide mixture, then positioned and retained in the bottom of each inoculation hole by driving another dowel piece, coated with the fungicide but not containing a pathogen, into each wound. This longer dowel piece was cut off flush with the branch surface and the wound was sealed with melted paraffin. The insertion of the dowel pieces into each hole expelled

Table 1. Influence of time of year and temperature on development of wood decay columns in Lisbon lemon branches

\begin{tabular}{|c|c|c|c|c|c|c|c|c|}
\hline \multirow[b]{3}{*}{ Time period ${ }^{y}$} & & & \multicolumn{6}{|c|}{ Length of wood decay column $(\mathrm{cm})^{x}$} \\
\hline & \multicolumn{2}{|c|}{ Air temperature $\left({ }^{\circ} \mathrm{C}\right)$} & \multicolumn{3}{|c|}{ First year } & \multicolumn{3}{|c|}{ Second year } \\
\hline & Year 1 & Year 2 & Ant. & Con. & Nod. & Ant. & Con. & Nod. \\
\hline November-January & 15.5 & 13.0 & $7.5 \mathrm{bA}$ & $1.0 \mathrm{cC}$ & $4.0 \mathrm{~dB}$ & $1.5 \mathrm{~dB}$ & $1.4 \mathrm{cB}$ & $2.2 \mathrm{dA}$ \\
\hline February-April & 18.5 & 17.0 & $6.8 \mathrm{bA}$ & $2.2 \mathrm{cB}$ & $6.3 \mathrm{cA}$ & $5.0 \mathrm{cA}$ & $2.4 \mathrm{cB}$ & $5.6 \mathrm{cA}$ \\
\hline May-July & 31.0 & 31.0 & $20.1 \mathrm{aA}$ & $5.6 \mathrm{bC}$ & $14.9 \mathrm{bB}$ & $18.4 \mathrm{aA}$ & $5.6 \mathrm{bC}$ & $15.2 \mathrm{aB}$ \\
\hline August-October & 28.5 & 29.5 & $20.8 \mathrm{aA}$ & $14.2 \mathrm{aB}$ & $19.5 \mathrm{aA}$ & $14.0 \mathrm{bA}$ & $13.6 \mathrm{aA}$ & $9.0 \mathrm{bB}$ \\
\hline ANOVA sources ${ }^{z}$ & & df & & $F$ & & $P>F$ & & \\
\hline Time period (TP) & & 3 & & 424.6 & & $<0.0001 * * *$ & & \\
\hline Pathogen $(\mathrm{P})$ & & 2 & & 141.5 & & $<0.0001 * * *$ & & \\
\hline Year (Y) & & 1 & & 68.4 & & $<0.0001 * * *$ & & \\
\hline $\mathrm{TP} \times \mathrm{P}$ & & 6 & & 28.7 & & $<0.0001 * * *$ & & \\
\hline $\mathrm{TP} \times \mathrm{Y}$ & & 3 & & 18.6 & & $<0.0001 * * *$ & & \\
\hline $\mathrm{P} \times \mathrm{Y}$ & & 2 & & 17.8 & & $<0.0001 * * *$ & & \\
\hline $\mathrm{TP} \times \mathrm{P} \times \mathrm{Y}$ & & 6 & & 6.2 & & $<0.0001 * * *$ & & \\
\hline
\end{tabular}

${ }^{\mathrm{x}}$ Each value is the mean length of wood decay column from 10 replicate branches from Lisbon lemon trees. Values in each column followed by a different lowercase letter, or in each row for the first or second year followed by a different uppercase letter, are significantly different $(P=0.05)$ according to the least significant difference test. Ant. $=$ Antrodia sinuosa, Con.$=$ Coniophora eremophila, and Nod.$=$ a Nodulisporium sp.; df $=$ degrees of freedom; $* * *=$ significant at $P<0.001$.

y Inoculation dates for the first year were 17 Nov 1999, 8 Feb 2000, 18 May and 25 Jul; and for the second year were 28 Oct 2000,31 Jan 2001, 3 May and 27 Jul. For the first year, disease development was assessed 84, 76, 90, and 95 days after inoculation, respectively; and for the second year 95, 92,84 , and 95 days after inoculation, respectively.

${ }^{\mathrm{z}}$ Analysis of variance (ANOVA) for sources of variation. Disease development time periods: November to January, February to April, May to July, and August to October. Pathogens: A. sinuosa, C. eremophila, and a Nodulisporium sp. Years: 1999-2000 and $2000-01$. 
the excess fungicide solution, leaving only a coating of the material on the surface of the hole and on the inserted pieces of dowel. Inoculation dates for the first and second year were 3 August 2000 and 24 July 2001, respectively. Disease development was assessed approximately 6 and 8 months later, respectively (7 February 2001 and 18 March 2002), by removing inoculated branches, splitting them in half, and measuring the resultant decay columns.

Analysis of data. CoStat statistical software (CoHort Software, Monterey, CA) was used to perform analysis of variance with the GLM procedure, to determine significant differences among main effects and any interactions, and to conduct linear regression analysis. Means were separated by the least significant difference test.

\section{RESULTS}

Effect of time of year on disease development. The main effects of time period, pathogen, and year, as well as the interactions of time period-pathogen, time period-year, pathogen-year, and time period-pathogen-year, on development of wood decay columns in Lisbon lemon branches all were significant (Table 1). For both runs of this experiment, the mean length of wood decay column recorded in lemon tree branches from November to January, February to April, May to July, and August to October when inoculated with all three wood rot pathogens was 2.9, 4.7, 13.3, and $15.2 \mathrm{~cm}$, respectively. For the same time periods, the mean air temperature was $14.2,17.8,31.0$, and $29.0^{\circ} \mathrm{C}$, respectively. There was a significant linear correlation between the length of wood decay column and air temperature on Lisbon lemon branches inoculated with $A$. sinuosa ( $r=0.946, P=0.0004$, described by the equation $y=0.92 x-9.49)$, $C$. eremophila ( $r=0.735, P=0.0379$, described by the equation $y=0.51 x-5.96)$, and the Nodulisporium sp. $(r=0.873, P=0.0047$, described by the equation $y=0.71 x-$

Table 2. Development of wood decay columns in inoculated branches of Lisbon lemon, Marsh grapefruit, and Valencia orange trees

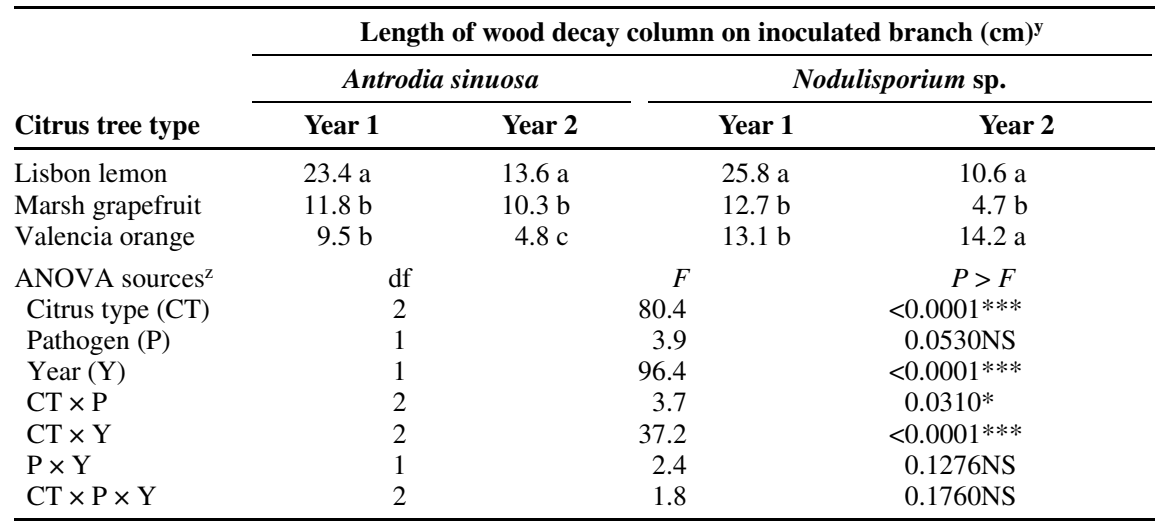

${ }^{y}$ Each value is the mean length of decay column from six branches of each type of citrus tree. Values in each column followed by a different letter are significantly different $(P=0.05)$ according to the least significant difference test.

${ }^{\mathrm{z}}$ Analysis of variance (ANOVA) for sources of variation. Plants: Lisbon lemon, Marsh grapefruit, and Valencia sweet orange. Pathogens: A. sinuosa and a Nodulisporium sp. Years: 2000 and 2001; df = degrees of freedom; $*$ and $* * *=$ significant at $P<0.05$ and 0.001 , respectively; NS $=$ not significant.
6.68). The mean length of wood decay column for all time periods in branches inoculated with $A$. sinuosa, C. eremophila, and the Nodulisporium sp. was $11.8,5.8$, and $9.6 \mathrm{~cm}$, respectively (Table 1 ).

Wood decay on different types of citrus. The main effects of citrus type, year, and the interactions of citrus typepathogen and citrus type-year on development of wood decay columns in inoculated branches all were significant (Table 2 ). Disease severity in branches inoculated with $A$. sinuosa, as determined by the length of wood decay columns, was significantly greater on Lisbon lemon trees compared with that developing on Marsh grapefruit and Valencia orange trees in both runs of this trial. For branches inoculated with the Nodulisporium sp., the severity of wood decay on lemon trees was greater than that recorded on Marsh grapefruit for both years and greater than Valencia orange for 1 year of the trial.

Wood decay on desert woody perennial plants. The main effects of desert plant, pathogen, year, and the interactions of desert plant-pathogen, desert plantyear, pathogen-year, and desert plantpathogen-year on development of wood decay columns in inoculated branches all were significant (Table 3). Among the desert perennial plants inoculated with $A$. sinuosa, wood decay columns on velvet mesquite were significantly longer than those on Mexican palo verde and creosote bush in both years of the experiment. Among tested plants inoculated with $C$. eremophila, wood decay was more severe in salt cedar compared with Mexican palo verde and creosote bush. C. eremophila caused virtually no decay in inoculated branches of creosote bush. When inoculated with the Nodulisporium sp., wood decay columns in branches of salt cedar and velvet mesquite were significantly longer than those in Mexican palo verde and creosote bush in both runs of this experiment (Table 3 ).

Table 3. Development of wood decay columns in inoculated branches of some desert woody perennial plants

\begin{tabular}{|c|c|c|c|c|c|c|}
\hline \multirow[b]{3}{*}{ Desert plant } & \multicolumn{6}{|c|}{ Length of wood decay column on inoculated branch $(\mathrm{cm})^{y}$} \\
\hline & \multicolumn{2}{|c|}{ Antrodia sinuosa } & \multicolumn{2}{|c|}{ Coniophora eremophila } & \multicolumn{2}{|c|}{ Nodulisporium sp. } \\
\hline & Year 1 & Year 2 & Year 1 & Year 2 & Year 1 & Year 2 \\
\hline Mexican palo verde & $1.2 \mathrm{~b}$ & $4.0 \mathrm{~b}$ & $1.5 \mathrm{~b}$ & $1.8 \mathrm{~b}$ & $2.4 \mathrm{~b}$ & $2.4 \mathrm{c}$ \\
\hline Salt cedar & $1.5 \mathrm{~b}$ & $6.0 \mathrm{a}$ & $9.0 \mathrm{a}$ & $3.6 \mathrm{a}$ & $12.8 \mathrm{a}$ & $6.4 \mathrm{a}$ \\
\hline Creosote bush & $2.0 \mathrm{~b}$ & $1.9 \mathrm{c}$ & $0.1 \mathrm{~b}$ & $0.1 \mathrm{c}$ & $4.4 \mathrm{~b}$ & $1.8 \mathrm{c}$ \\
\hline Velvet mesquite & $6.0 \mathrm{a}$ & $6.1 \mathrm{a}$ & $6.4 \mathrm{a}$ & $2.4 \mathrm{~b}$ & $9.8 \mathrm{a}$ & $4.8 \mathrm{~b}$ \\
\hline ANOVA sources ${ }^{z}$ & & df & & $F$ & & $P>F$ \\
\hline Desert plant (DP) & & 3 & & 68.1 & & $<0.0001 * * *$ \\
\hline Pathogen $(\mathrm{P})$ & & 2 & & 26.3 & & $<0.0001 * * *$ \\
\hline Year $(Y)$ & & 1 & & 19.6 & & $<0.0001^{* * *}$ \\
\hline $\mathrm{DP} \times \mathrm{P}$ & & 6 & & 7.8 & & $<0.0001 * * *$ \\
\hline $\mathrm{DP} \times \mathrm{Y}$ & & 3 & & 9.1 & & $<0.0001 * * *$ \\
\hline $\mathrm{P} \times \mathrm{Y}$ & & 2 & & 28.6 & & $<0.0001 * * *$ \\
\hline $\mathrm{DP} \times \mathrm{P} \times \mathrm{Y}$ & & 6 & & 5.3 & & $<0.0001 * * *$ \\
\hline
\end{tabular}

y Each value is the mean length of decay column from 10 branches of each type of woody perennial plant. Values in each column followed by a different letter are significantly different $(P=0.05)$ according to the least significant difference test.

${ }^{\mathrm{z}}$ Analysis of variance (ANOVA) for sources of variation. Plants: Mexican palo verde, salt cedar, creosote bush, and velvet mesquite. Pathogens: A. sinuosa, C. eremophila, and Nodulisporium sp. Years: 2000 and 2001; $\mathrm{df}=$ degrees of freedom; *** $=$ significant at $P<0.001$. 
Fungicide studies. The main effects of pathogen, fungicide treatment, and year, as well as the interactions of pathogenfungicide treatment, pathogen-year, fungicide treatment-year, and pathogenfungicide treatment-year on development of wood decay columns in inoculated Lisbon lemon tree branches all were significant (Table 4). In both runs of this trial, propiconazole and azoxystrobin at a rate of $20 \mathrm{mg}$ a.i./ml were either equivalent to or more effective than other tested fungicides in suppressing wood decay column development in Lisbon lemon tree branches inoculated with A. sinuosa, C. eremophila, and the Nodulisporium sp. Compared with nontreated but inoculated branches, the length of wood decay columns in branches inoculated with A. sinuosa, C. eremophila, and the Nodulisporium sp. in the presence of propiconazole was reduced by 79,94 , and $92 \%$, respectively, and, in the presence of azoxystrobin, was suppressed by 71,80 , and $89 \%$, respectively. Pyraclostrobin significantly reduced the length of wood decay columns in both runs of the trial when branches were inoculated with $A$. sinuosa and the Nodulisporium sp. (mean reduction of 52 and $85 \%$, respectively) and in one of two trials when branches were inoculated with $C$. eremophila (mean reduction of $80 \%$ ). Trifloxystrobin significantly reduced wood decay in both runs of the trial when branches were inoculated with C. eremophila and the Nodulisporium sp. and in one run when branches were inoculated with $A$. sinuosa, whereas kresoxim-methyl significantly reduced the length of wood decay columns in both runs when trees were inoculated with the Nodulisporium sp. and in one run when the pathogen was A. sinuosa or C. eremophila (Table 4).

In all studies, A. sinuosa, C. eremophila, and the Nodulisporium sp. subsequently were recovered from decayed wood tissue from branches inoculated with these pathogens. On the other hand, no wood decay was observed in branches of trees receiving dowel pieces not colonized by one of these wood rot pathogens.

\section{DISCUSSION}

In Arizona, three fungi, A. sinuosa, $C$. eremophila, and a Nodulisporium sp., have been isolated from living lemon trees with symptoms of wood rot. Inoculation of lemon trees with these fungi and the subsequent reisolation of these pathogens from wood decay columns that developed on inoculated branches have fulfilled Koch's postulates.

The initial symptoms of wood rot caused by $A$. sinuosa, C. eremophila, and the Nodulisporium sp. are wilting and dying of leaves on infected branches of lemon trees. These symptoms appear during the hot summer and early autumn months from July to October, suggesting that the causal pathogens are most active during this time of the year. Our studies revealed that wood decay in the presence of these pathogens was significantly greater from May through October compared with November through April. There is an apparent lag time from onset of increased wood rot development in late spring to the appearance of wilting and dying leaves and dieback of branches beginning in early summer. Bigelow et al. (2) found that isolates of $A$. sinuosa and $C$. eremophila recovered from lemon trees in Arizona had an optimal growth temperature ranging from 30 to $35^{\circ} \mathrm{C}$ on malt extract agar. On the other hand, growth at 15 to $20^{\circ} \mathrm{C}$ was lower than optimal by 73 to $87 \%$ and from 67 to $97 \%$ for isolates of $A$. sinuosa and $C$. eremophila, respectively. Similar declines in wood rot development were observed on lemon tree branches inoculated with these pathogens from November through April, when mean air temperatures ranged from 13 to $18.5^{\circ} \mathrm{C}$, compared with May through October, when mean air temperatures ranged from 28.5 to $31^{\circ} \mathrm{C}$.

Previous research had shown that the length of wood decay columns in Lisbon lemon branches inoculated with $C$. eremophila was significantly greater than that in branches of Marsh grapefruit and Valencia orange (3). We found similar results when these types of citrus trees were inoculated with A. sinuosa and with the Nodulisporium $\mathrm{sp}$. in one of two trials. Several different types of citrus, including lemon, orange, and grapefruit, are grown in Arizona; however, virtually all detected occurrences of wood rot caused by A. sinuosa, C. eremophila, and the Nodulisporium sp. have been on lemon trees. Increased susceptibility of lemon wood to decay by these three pathogens, compared with grapefruit and orange trees, may partially explain the virtual limitation of naturally occurring wood rot to lemon trees. However, the growth habit of lemon compared with grapefruit and orange trees may have a more profound impact on natural development of wood decay. Lemon trees grow more vigorously than grapefruit and orange trees. In Arizona, commercial plantings of lemon, but usually not grapefruit and orange trees, are pruned and hedged to maintain trees at a manageable size. Due to their vigorous growth habit and heavy fruit loads, branches on lemon trees often sustain partial fractures. Picking ladder injury increases damage to smaller limbs of trees. The resulting cracks in fractured limbs and branches are the primary sites where wood rot initially develops on lemon trees. On the other hand, fracturing of branches on grapefruit and orange trees in Arizona is uncommon.

Table 4. Effect of fungicides on development of wood decay columns in Lisbon lemon branches

\begin{tabular}{|c|c|c|c|c|c|c|}
\hline \multirow[b]{3}{*}{ Treatment (20 mg a.i./ml) } & \multicolumn{6}{|c|}{ Length of wood decay column on inoculated branch $(\mathbf{c m})^{y}$} \\
\hline & \multicolumn{2}{|c|}{ Antrodia sinuosa } & \multicolumn{2}{|c|}{ Coniophora eremophila } & \multicolumn{2}{|c|}{ Nodulisporium sp. } \\
\hline & Year 1 & Year 2 & Year 1 & Year 2 & Year 1 & Year 2 \\
\hline Nontreated & $15.9 \mathrm{a}$ & $14.0 \mathrm{a}$ & $4.5 \mathrm{a}$ & $17.8 \mathrm{a}$ & $14.8 \mathrm{a}$ & $13.9 \mathrm{a}$ \\
\hline Azoxystrobin & $6.2 \mathrm{c}$ & $2.7 \mathrm{~b}$ & $0.3 \mathrm{c}$ & $4.1 \mathrm{~b}$ & $2.1 \mathrm{c}$ & $1.0 \mathrm{c}$ \\
\hline Kresoxim-methyl & $13.1 \mathrm{ab}$ & $3.1 \mathrm{~b}$ & $2.8 \mathrm{ab}$ & $2.2 b c$ & $7.0 \mathrm{~b}$ & $1.2 \mathrm{c}$ \\
\hline Propiconazole & $3.6 \mathrm{c}$ & $2.7 \mathrm{~b}$ & $0.6 \mathrm{c}$ & $0.8 \mathrm{c}$ & $1.5 \mathrm{c}$ & $0.8 \mathrm{c}$ \\
\hline Pyraclostrobin & $10.5 \mathrm{~b}$ & $3.8 \mathrm{~b}$ & $3.0 \mathrm{ab}$ & $1.5 \mathrm{bc}$ & $3.4 \mathrm{bc}$ & $0.9 \mathrm{c}$ \\
\hline Trifloxystrobin & $16.0 \mathrm{a}$ & $5.7 \mathrm{~b}$ & $1.8 \mathrm{bc}$ & $2.4 \mathrm{bc}$ & $44 \mathrm{bc}$ & $3.9 \mathrm{~b}$ \\
\hline ANOVA sources ${ }^{2}$ & & df & & $F$ & & $P>F$ \\
\hline Pathogen (P) & & 2 & & 59.0 & & $<0.0001 * * *$ \\
\hline Fungicide $(\mathrm{F})$ & & 5 & & 89.7 & & $<0.0001 * * *$ \\
\hline Year $(\mathrm{Y})$ & & 1 & & 19.7 & & $<0.0001 * * *$ \\
\hline $\mathrm{P} \times \mathrm{F}$ & & 10 & & 3.6 & & $0.0001 * * *$ \\
\hline $\mathrm{P} \times \mathrm{Y}$ & & 2 & & 42.5 & & $<0.0001 * * *$ \\
\hline $\mathrm{F} \times \mathrm{Y}$ & & 5 & & 13.2 & & $<0.0001 * * *$ \\
\hline $\mathrm{P} \times \mathrm{F} \times \mathrm{Y}$ & & 10 & & 4.3 & & $<0.0001 * * *$ \\
\hline
\end{tabular}

${ }_{\mathrm{y}}$ Each value is the mean length of decay column from 10 Lisbon lemon tree branches. Values in each column followed by a different letter are significantly different $(P=0.05)$ according to the least significant difference test.

${ }^{\mathrm{z}}$ Analysis of variance (ANOVA) for sources of variation. Pathogens: A. sinuosa, C. eremophila, and Nodulisporium sp. Fungicide treatments: nontreated control, azoxystrobin, kresoxim-methyl, pyraclostrobin, trifloxystrobin, and propiconazole. Years: 2000 and 2001; df = degrees of freedom; $* * *=$ significant at $P<0.001$. 
The ability of A. sinuosa, C. eremophila, and the Nodulisporium sp. to cause wood decay in living desert perennial plants was evaluated to assess the potential threat of these plants as sources of inoculum for lemon tree infection. C. eremophila has been found fruiting on a number of species of desert trees, shrubs, and cacti, including velvet mesquite, mainly as a saprobe on dead fallen wood and associated with a brown rot (9-11). Our studies confirmed that A. sinuosa and the Nodulisporium sp., in addition to $C$. eremophila, could cause wood decay in living branches of velvet mesquite, which is a common desert plant in the Yuma area, where a majority of Arizona lemon groves are located. When inoculated with each of these wood rot pathogens, wood decay also developed in salt cedar and, to a lesser extent, in Mexican palo verde, two other abundant plants found in the Yuma area. Wood decay also developed on another common desert plant in the region, creosote bush, when inoculated with A. sinuosa and the Nodulisporium sp. However, wood decay in these circumstances occurred as a result of artificial inoculation of branches with mycelium of each pathogen. Further research is needed to determine whether or not wood from living or dead velvet mesquite, salt cedar, Mexican palo verde, creosote bush, or other desert or ornamental perennial plants could be colonized by airborne spores of these fungi. Additionally, each pathogen must be capable of sporulating on these substrates to be a threat to nearby lemon tree plantings. Until this information is known, we will not know if wood from one or more desert or ornamental plants could serve as a source of inoculum for lemon tree infections. Another potential source of inoculum could be infected lemon trees. A. sinuosa has been found fruiting on infected branches within living lemon trees; however, fruiting on branches infected with C. eremophila or the Nodulisporium sp. has not yet been observed.

Among tested fungicides, propiconazole and azoxystrobin provided the greatest degree of overall suppression of wood decay in lemon tree branches inoculated with mycelium of $A$. sinuosa, C. eremophila, and the Nodulisporium sp. Sustained suppression of growth of wood decay in a lemon tree would require periodic injection of a fungicide into the tree, a procedure that likely would be cost prohibitive even if technically feasible. Preventative application of fungicides to wounds or branch fractures could be an effective disease management strategy; however, research to prove the efficacy of such treatments remains to be conducted.

Currently, wood rot caused by $A$. sinuosa, C. eremophila, and the Nodulisporium sp. is managed by early detection and removal of infected lemon tree branches. Removal of infected branches should be completed before the onset of increased growth of wood decay columns that occurs from May to October. Cultural practices that minimize fracturing of branches and other nonpruning wounds also are encouraged, which should reduce the number of potential infection sites on lemon trees.

\section{LITERATURE CITED}

1. Anonymous. 1984. Integrated pest management for citrus. University of California Statewide IPM Project. Div. Agric. Nat. Res. Publ. 3303.

2. Bigelow, D. M., Gilbertson, R. L., and Matheron, M. E. 1998. Cultural studies of fungi causing brown rot in heartwood of living lemon trees in Arizona. Mycol. Res. 102:257-262.

3. Bigelow, D. M., Matheron, M. E., and Gilbertson, R. L. 1996. Biology and control of Coniophora eremophila on lemon trees in Arizona. Plant Dis. 80:934-939.

4. Bigelow, D. M., Matheron, M. E., and Gilbertson, R. L. 1999. Antrodia sinuosa is significant in brown heartwood rot of living lemons in Arizona. (Abstr.) Phytopathology 89:S7.

5. Broadbent, P. 1981. Armillaria root rot of citrus in New South Wales, Australia. Proc. Int. Soc. Citric. 1:351-353.

6. Burns, R. M., Klotz, L. J., and Platt, R. G. 1975. Identifying Ganoderma fungus. Citrograph 60(3):86 and 90.

7. Farr, D. F., Bills, G. F., Chamuris, G. P., and Rossman, A. Y. 1989. Fungi on Plant and Plant
Products in the United States. American Phytopathological Society, St. Paul, MN.

8. French, A. M. 1987. California plant disease host index. Part I. Fruit and Nuts. California Department of Food and Agriculture, Sacramento.

9. Gilbertson, R. L., Burdsall, H. H., and Canfield, E. R. 1976. Fungi that decay mesquite in southern Arizona. Mycotaxon 3:487-551.

10. Gilbertson, R. L., Goldstein, D., and Lindsey, J. P. 1979. Additions to the check list and host index for Arizona wood-rotting fungi. J. Ariz.Nev. Acad. Sci. 14:81-87.

11. Gilbertson, R. L., Martin K. J., and Lindsey, J. P. 1974. Annotated check list and host index for Arizona wood rotting fungi. Univ. Ariz. Agric. Exp. Stn. Tech. Bull. 209:1-48.

12. Klotz, L. J. 1973. Color Handbook of Citrus Diseases, 4th ed. University of California Division of Agricultural Science, Berkeley.

13. Knorr, L. C. 1973. Citrus Diseases and Disorders. The University Presses of Florida Gainesville.

14. Lindsey, J. P., and Gilbertson, R. L. 1975. Wood-inhabiting homobasidiomycetes on saguaro in Arizona. Mycotaxon 2:83-103.

15. Matheron, M. E., Gilbertson, R. L., and Matejka, J. C. 1992. Coniophora sp. implicated in rapid development of wood rot on living branches of lemon trees in Arizona. (Abstr.) Phytopathology 82:1083.

16. Matheron, M. E., and Porchas, M. 2002. Nodulisporium sp. implicated in death of branches on lemon trees in Arizona. (Abstr.) Phytopathology 92:S52.

17. Munnecke, D. E., Kolbezon, M. J., Wilbur, W. D., and Ohr, H. D. 1981. Interactions involved in controlling Armillaria mellea. Plant Dis. 65:384-389.

18. Sinclair, W. A., Lyon, H. H., and Johnson, W. T. 1987. Diseases of Trees and Shrubs. Comstock Publication Associates, Cornell University Press, Ithaca, NY.

19. Skaria, M. 1990. A pictorial analysis of the growth and development of Ganoderma rot on young citrus in Texas. J. Rio Grande Val. Hortic. Soc. 43:85-87.

20. Skaria, M., Smith, G. S., and Gilbertson, R. L. 1990. Root rot of young citrus caused by a species of the Ganoderma lucidum complex. (Abstr.) Phytopathology 80:974

21. Whiteside, J. O. 2000. Wood rot. Page 36 in: Compendium of Citrus Diseases. L. W. Timmer, S. W. Garnsey, and J. H. Graham, eds. American Phytopathological Society Press, St. Paul, MN.

22. Whiteside, J. O., and Knorr, L. C. 1970. Mushroom root rot-an easily overlooked cause of citrus tree decline. Citrus Ind. 51:17-20. 